\title{
Obesity and colorectal cancer: molecular features of adipose tissue
}

\author{
Javier Martinez-Useros ${ }^{*}$ and Jesus Garcia-Foncillas
}

\begin{abstract}
The huge part of population in developed countries is overweight or obese. Obesity is often determined by body mass index (BMI) but new accurate methods and ratios have recently appeared to measure body fat or fat located in the intestines. Early diagnosis of obesity is crucial since it is considered an increasing colorectal cancer risk factor. On the one hand, colorectal cancer has been strongly associated with lifestyle factors. A diet rich in red and processed meats may increase colorectal cancer risk; however, high-fiber diets (grains, cereals and fruits) have been associated with a decreased risk of colorectal cancer. Other life-style factors associated with obesity that also increase colorectal cancer risk are physical inactivity, smoking and high alcohol intake. Cutting-edge studies reported that high-risk transformation ability of adipose tissue is due to production of different pro-inflammatory cytokines like IL-8, IL-6 or IL-2 and other enzymes like lactate dehydrogenase (LDH) and tumour necrosis factor alpha (TNFa). Furthermore, oxidative stress produces fatty-acid peroxidation whose metabolites possess very high toxicities and mutagenic properties. 4-hydroxy-2-nonenal (4-HNE) is an active compounds that upregulates prostaglandin E2 which is directly associated with high proliferative colorectal cancer. Moreover, 4-HNE deregulates cell proliferation, cell survival, differentiation, autophagy, senescence, apoptosis and necrosis via mitogen-activated protein kinase (MAPK), phosphoinositide 3-kinase (PIK3CA) — AKT and protein kinase C pathways. Other product of lipid peroxidation is malondialdehyde (MDA) being able to regulate insulin through WNT-pathway as well as having demonstrated its mutagenic capability. Accumulation of point mutation enables genomic evolution of colorectal cancer described in the model of Fearon and Vogelstein. In this review, we will summarize different determination methods and techniques to assess a truthfully diagnosis and we will explain some of the capabilities that performs adipocytes as the largest endocrine organ.
\end{abstract}

Keywords: Colorectal cancer, Obesity, Overweight, BMI, Adipose tissue, Cytokines, Inflammation, 4-HNE, MDA, MPE

\section{Background}

In western countries a huge part of population is overweight or obese, for example in the US more than $30 \%$ of the population belong to this group [1]. In the UK obesity is considered the second cancer risk-factor after smoking [2]. Obesity refers a disorder that involves excessive accumulation of body fat and thereof, raising the risk of metabolic syndrome. Obesity is one of the risk factors such as gender, race, dietary habits or smoking history that has been linked to the most relevant cancers like breast [3], gynaecological [4], liver [5] and colorectal cancer (CRC) [6]. Colorectal cancer is one of the most common

*Correspondence: javier.museros@oncohealth.eu

Translational Oncology Division, Oncohealth Institute, FllS-Fundacion Jimenez Diaz, Av. Reyes Catolicos 2, 28040 Madrid, Spain gastrointestinal malignant tumours in the world and presents one of the highest rates of morbidity and mortality worldwide [7]. In addition, colorectal cancer-obesity relationship is reinforced by the importance of nutrition in this cancer. Thus, colon cancer has been associated with red and processed meat intake [8]. Moreover, a dietary pattern based on high-carbohydrate intake, and high-sugar content beverages after colorectal cancer diagnosis may increase risk of recurrence and mortality after colorectal cancer diagnosis $[9,10]$. Besides, folate deficiency in diet induce tumourigenesis and MTHFR (methylenetetrahydrofolate reductase) gene depletion produces a defect in DNA repair [11, 12]. Another factor that indirectly influences colon cancer is smoking [13-15]. Cigarette smoke induces prostaglandin E2 synthesis [16] and in high concentrations are considered 
a high-risk factor for colon cancer [17, 18]. Moreover, high levels of prostaglandin E2 in rectal mucosa has been directly correlated with high body mass index (BMI) [19]. Also high BMI was associated with a significantly highrisk of CRC with no or weak expression of fatty acid synthase [20] and $\beta$-catenin-negative colonic tumours [21]. Above all determination methods to diagnose obesity BMI are widespread used. Body mass index has been proposed as a ratio to predict high-risk colorectal neoplasias [22]. This association may be due to the large spectrum of cytokines and metabolites produced by adipose tissue which exhibit pro-inflammatory and cancer prone characteristics. In fact, cytokines produced by adipose tissue triggers insulin resistance [23] and mediates proliferation, migration, angiogenesis [24] and induction of oxidative stress [25]. The more influential products of oxidative stress are 4-hydroxy-2-nonenal (4-HNE) and malondialdehyde (MDA). Both compounds produced in the adipose tissue have an extraordinary effect on whole body metabolism. In this review we will highlight the relationship between obesity and CRC and the importance to consider obesity in the standard of care dealing with colorectal cancer patients.

\section{Review \\ Methods to determine obesity in their connection with CRC}

Some reports have proposed waist circumference instead of height $[26,27]$ for the determination of some obesity ratios. This is the case of waist-to-hip ratio [28], that seems to achieve significance with a higher CRC risk in men but not in women [29]. Other ratios are recently used to determine obesity and correlate with CRC, like impedance analysis [30], visceral fat tissue amount (VAT) [31-33] or visceral-to-subcutaneous fat ratio [34-36] (Table 1). Nevertheless, the most common ratio to diagnose obesity is by using BMI that must be $30 \mathrm{~kg} / \mathrm{m}^{2}$ or greater. Still, abdominal visceral and subcutaneous adipose tissue is considered more accurate and pathogenic than BMI [37].

\section{BMI}

Body mass index, also called Quetelet index, is expressed as weight in kilograms/height in meter square [38]. A large number of studies have reported an association between high BMI and colorectal cancer. For example, a study conducted by the American Cancer Society [39] the risk associated with high BMI (above $30 \mathrm{~kg} / \mathrm{m}^{2}$ ) was 1.8 for men and 1.2 for women compared with a BMI below $25 \mathrm{~kg} / \mathrm{m}^{2}$. Other reports found a stronger association between BMI and colorectal cancer in different countries [40-43], but this association was rather controversial according to sex in other studies [44, 45]. Early life body fatness would be associated with a higher risk of developing colorectal cancer. Here, the relative risks comparing BMI categories $\geq 27.5-<19 \mathrm{~kg} / \mathrm{m}^{2}$ were $1.44(1.06-1.95$, at age $18 ; \mathrm{P}=0.009)$ for women and $1.18(0.84-1.65$, at age $21 ; \mathrm{P}=0.57$ ) for men [46].

The association between colorectal cancer risk and $\mathrm{BMI}$ is, in general, stronger for cancers localised in the distal colon than other localizations [43-45, 47]. Concerning rectal cancer some studies have shown scarce evidence for a connection with BMI $[41,45]$. Body mass index was also related to higher risk of colon polyps or adenomas specially in male population [48].

\section{VAT}

Visceral adipose tissue (VAT) could be easily quantified by computerized tomography [31], and has been identified as a risk factor for colorectal adenomas [49] and carcinomas $[32,50]$.

Although not always VAT was associated with risk of colon adenomas [51], in other studies high VAT showed a statistical significant association between proximal, multiple and advanced adenomas $(\mathrm{p}<0.05)$ [49]. These findings related VAT index with the development and progression of colorectal adenoma, and it turned out to be a more appropriate obesity index for colorectal adenoma than BMI in both sexes [49]. Compared to subcutaneous adipose tissue, VAT revealed high levels of markers of inflammatory lipid metabolism and some of them associated with CRC tumour stage [50]. Concerning chemotherapy resistance VAT has been considered a poor prognostic marker in CRC receiving adjuvant chemotherapy [52]. Patients with high VAT had a significantly lower overall survival ( 54.8 vs $87.1 \%, \mathrm{P}=0.004)$ and disease-free survival (48.4 vs $77.4 \%, \mathrm{P}=0.007$ ) if compared to patients with low VAT. Furthermore, VAT was independently associated to a reduced overall survival $(\mathrm{HR}=7.0$; $95 \% \mathrm{CI} 2.0-24.6 ; \mathrm{p}=0.002)$ [52]. But it is not always the case, other authors support low VAT could be poor prognosis marker during chemotherapy administration because it could lead to nutritional supply impairment and a subsequent malnutrition [53, 54].

However, VAT has been acknowledged to be more pathogenic than BMI [55].

\section{Biologic performances of obesity \\ Obesity as a mutagenic factor for CRC}

There are multiple molecular pathways to metabolize fat in the adipocytes. One of the mechanisms to process that fat is by peroxidation [56]. However, when cell has to manage with medium or high rates of lipid peroxidation reaction turns into toxic conditions and oxidative stress abate DNA repair capability, and then cells induce apoptosis that leads to disease $[57,58]$. Two of the products of 
Table 1 Methods and ratios more commonly used to determine obesity

\begin{tabular}{|c|c|c|c|}
\hline Index & Range & & Ref. \\
\hline \multirow[t]{4}{*}{ Body mass index $\left(\mathrm{kg} / \mathrm{m}^{2}\right)$} & \multicolumn{2}{|l|}{ Underweight < 18.5} & {$[38]$} \\
\hline & \multicolumn{2}{|l|}{$18.5<$ Normal $<24.9$} & \\
\hline & \multicolumn{2}{|l|}{$25<$ Overweight $<29.9$} & \\
\hline & \multicolumn{2}{|l|}{$30<$ Obesity } & \\
\hline Visceral adiposity ratio & Moderate & Severe & {$[31]$} \\
\hline$<30$ years & $2.59-2.73$ & $>2.73$ & \\
\hline$\geq 30<42$ years & $2.54-3.12$ & $>3.12$ & \\
\hline$\geq 42<52$ years & $2.17-2.77$ & $>2.77$ & \\
\hline$\geq 52<66$ years & $2.32-3.25$ & $>3.25$ & \\
\hline$\geq 66$ years & $2.42-3.17$ & $>3.17$ & \\
\hline \multirow[t]{4}{*}{ Waist-to-hip ratio } & Women & Men & {$[28]$} \\
\hline & Normal $<0.8$ & Normal $<0.9$ & \\
\hline & $0.81<$ Overweight $<0.84$ & $0.91<$ Overweight $<0.99$ & \\
\hline & $0.85<$ Obesity & $1.00<$ Obesity & \\
\hline \multirow[t]{6}{*}{ Waist-to-height ratio } & Women & Men & {$[26,27]$} \\
\hline & Extremely slim < 0.34 & Extremely slim < 0.34 & \\
\hline & $0.35<\operatorname{Slim}<0.41$ & $0.35<$ Slim $<0.42$ & \\
\hline & $0.42<$ Healthy $<0.48$ & $0.43<$ Healthy $<0.52$ & \\
\hline & $0.49<$ Overweight $<0.53$ & $0.53<$ Overweight $<0.57$ & \\
\hline & $0.54<$ Obesity & $0.58<$ Obesity & \\
\hline \multirow[t]{4}{*}{ Biolectrical impedance (\% fat) } & Women & Men & {$[30]$} \\
\hline & $28.3 \pm 5.1$ Normal & $18.0 \pm 4.5$ Normal & \\
\hline & $35.7 \pm 2.8$ Overweight & $23.3 \pm 4.2$ Overweight & \\
\hline & $41.6 \pm 3.9$ Obese & $31.2 \pm 5.1$ Obese & \\
\hline Visceral-to-subcutaneous fat ratio & \multicolumn{2}{|c|}{ Healthy (gynoid fat) < 0,4 < Risk (android fat) } & [34-36] \\
\hline
\end{tabular}

lipid peroxidation are 4-hydroxy-2-nonenal (4-HNE) and malondialdehyde (MDA). While MDA is a highly mutagenic compound, 4-HNE is basically toxic and functions as deregulators of different molecular pathways $[59,60]$.

4-hydroxy-2-nonenal is nowadays considered as the major bioactive marker of lipid peroxidation and a signaling molecule involved in the regulation of several transcription factors sensible to stress [61]. Some of these factors are activating protein-1 (AP-1), NF-kB, and peroxisome-proliferator-activated receptors (PPAR). Activating protein-1 transcription factor control cell proliferation, survival, and death. Growth factors, cytokines, cellular stress, and many other stimuli activate AP-1 [62]. $\mathrm{NF}-\mathrm{kB}$ induce gene transcription of genes involved in the regulation of inflammation [63]. Peroxisome-proliferator-activated receptors act as key transcriptional regulators of lipid metabolism, mitochondrial biogenesis, and antioxidant defence [64]. 4-hydroxy-2-nonenal increase PPAR gene expression and accelerate adiponectin protein degradation in adipocytes [65]. Peroxisome-proliferatoractivated receptors has been also reported to arrest colorectal cancer proliferation $[66,67]$, however it has also been linked to poor outcome in metastatic colorectal cancer (mCRC) [68]. 4-hydroxy-2-nonenal also upregulates prostaglandin E2 [69] and cyclooxygenase-2 (COX2) [70], two factors associated with high proliferative colorectal cancer [71].

Furthermore, 4-HNE is involved in cell proliferation, differentiation, cell survival, autophagy, senescence, apoptosis and necrosis via activation of mitogen-activated protein kinases (MAPK), PIK3CA-AKT pathways, and protein kinase C. Some of the factors included in the MAPK pathway are ERK, P38, and JUN. Mitogenactivated protein kinases signaling pathway has been one of the most altered molecular mechanism in CRC [72, 73]. Interestingly, $R A S / R A F$ mutations are the most commonly found alteration in colorectal cancers $[74,75]$.

In oxidative stress conditions, an important cellular response is the activation of the PIK3CA-AKT pathway that involves the oxidation and subsequent inactivation of PTEN, a tumour suppressor gene [76]. Both molecular pathways are connected by EGFR that has improved colorectal cancer classification and treatment [77].

Protein kinases C (PKCs) are a family of multifunctional enzymes that play crucial roles in the transduction of many cellular signals such as control of cell 
proliferation, survival, and transformation by phosphorylating various targets. Protein kinases $\mathrm{C}$ can also be activated by oxidative stress [78]. Moreover, oxidative stress produces a wide range of DNA mutations [79] by exogenous oxidative stimuli like high levels of alkylating agents [80], radiation [81], antioxidant depletion [82] or during inflammation process [83].

Malondialdehyde has shown to be a highly mutagenic agent in eukaryotic cells [84] and also has tumourigenic properties [85]. MDA regulated islet glucose-stimulated insulin secretion through WNT pathway [86]. Under stress conditions MDA has high ability to react with proteins or DNA that leads to the formation of adducts [87], and its aberrant expression has been associated with different pathologies [88-91]. This fact is due to the capability of MDA to react physiologically with several nucleosides (deoxy-guanosine and cytidine) to form adducts to deoxyguanosine and deoxyadenosine, resulting in pyrimido(1,2-a)purin-10(3H-)one (M1-dG) [84, 92]. In contrast, vitamins intake was associated with reduced levels of M1-dG [93] that supports the role of vitamins as a protective factor against cancer.

Accumulation of mutation in crucial factors enable the genetic process of CRC described initially by Fearon and Vogelstein and updated with experts recommendations by Rex et al. (Fig. 1) [94, 95]. Here, serrated CRC arise from adenomas in a process that in most people takes at least 10 years. The initiation of CRC involves several genetic alterations that begins with chromosomal instability (CIN), which causes numerous changes in chromosomal structure and copy number [96]. Chromosomal instability is an efficient mechanism that causes the loss of a wild-type copy of tumour-suppressor genes, such as

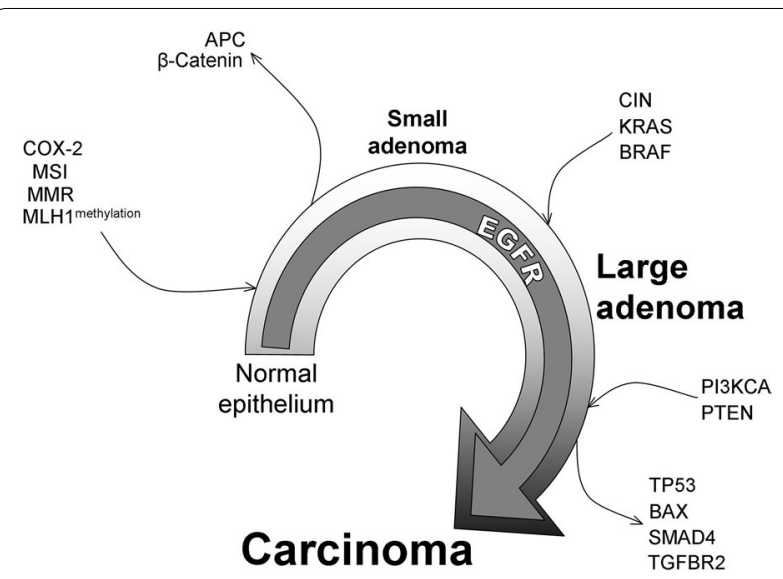

Fig. 1 Transformation model of CRC. Ingoing arrows concern oncogenic effectors that are turned on in the cancer progression. Outgoing arrows highlight tumour suppressor factors that become inactivated in colon cancer
APC, TP53 or SMAD family member 4 (SMAD4) [97]. Other key event in colorectal cancer initiation is the induction of COX-2, throughout EGFR pathway [98], that mediates the synthesis of prostaglandin E2, an agent strongly associated with colorectal cancer development, stem cell expansion and metastasis [99, 100]. The most commonly found mutation in colorectal cancer involves the APC protein that leads its inactivation. In the absence of functional APC, oncogenic WNT-Catenin beta 1 (CTNNB1) pathway is activated [97, 101]. APC mutations is associated to familial adenomatous polyposis [102, 103]. MLH1 confers a lifetime risk of colorectal cancer of about $80 \%$ and the methylation status is an effective biomarker for Lynch Syndrome [104-106]. Mismatch-repair deficiency (MMR) leads the inactivation of some anti-tumour factors $[107,108]$ such as transforming growth factor $\beta$ (TGF- $\beta$ ) receptor type II (TGFBR2) [109], BCL2-associated X protein (BAX), Caspase-5 and TP53 [110-113]. Furthermore, the microsatellite instability (MSI) pathway, crucial for cancer progression, is initiated by $M M R$ mutation or by $M L H 1$ methylation [114]. Interestingly, MSI status in colonic tumours has been associated to obesity, cigarette smoking, refined carbohydrate, and red meat consumption [115-117].

Several oncogenes promote colorectal cancer development. Oncogenic mutations of RAS (including NRAS and $K R A S$ ) and $B R A F$, which activate the MAPK signaling pathway, occur in 37 and $13 \%$ of colorectal cancers, respectively [118-120]. Brändstedt et al. reported statistically significant association between high waist-to-hip (WHR) ratio and BMI with an increased risk of KRASmutated colorectal tumours in men. However, in women only high WHR was significantly associated with an increased risk of KRAS-mutated colorectal cancers [121]. In addition, $33 \%$ of colorectal cancers carry activating somatic mutations in PIK3CA, which encodes the catalytic subunit of phosphatidylinositol 3-kinase [122]. Other alterations involve loss of PTEN [123, 124]. EGFR is essential for CRC initiation and development which triggers MAPK and PIK3CA-AKT signaling pathway [125-128].

On the other hand, adipose tissue produces biochemical compounds involved in deregulation of whole-body metabolism and affect evolution of CRC.

\section{Obesity promotes deregulation of metabolism}

Obesity leads co-morbidities like diabetes, impairment in lipid metabolism and endocrinologic changes that allow cancer progression (Fig. 2) [129]. For example, the regulation of aromatase in mammary fat-tissues is interesting for clinical practise specially dealing with breast hormone-dependent cancers [130, 131]. Adipose tissues have long been identified as significant sites for steroid hormone transformation and action [132]. In addition, 


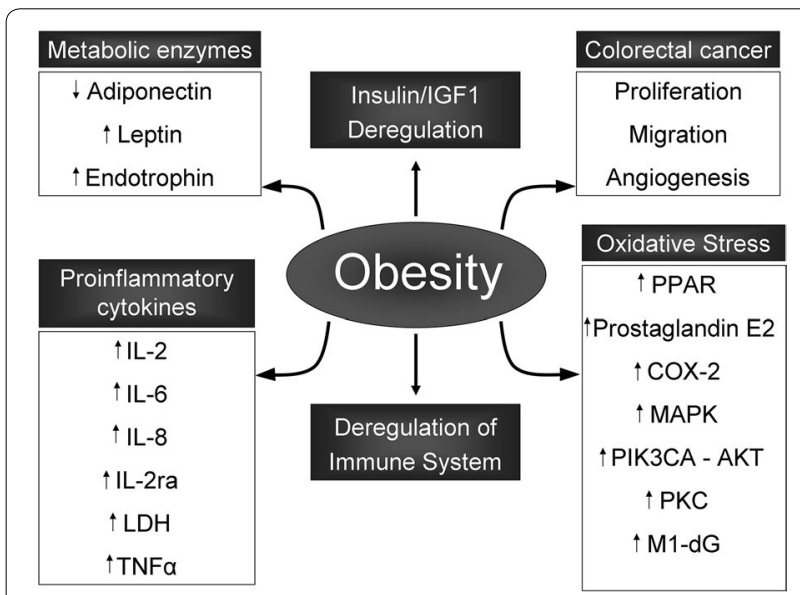

Fig. 2 Schematic diagram of biochemical features of obesity. Up and down arrows denote up- or downregulation respectively

obese patients commonly present deregulation of insulin and/or insulin growth factor 1 (IGF1) that has also been linked to cancer [133] because insulin is considered a strong mitogen factor and stimulates DNA synthesis [134]. In fact, glucose and insulin levels exhibited statistically significant associations with colorectal cancer $[135,136]$ because their ability to increase the proportion of cells with metabolically active mitochondria [137]. In respect to IGF1, different studies support the role of this factor in colorectal carcinogenesis [138-140], chemoresistance [141], metastasis [142, 143] and prevention from apoptosis [144, 145].

Other obesity proteins are directly related to CRC. This is the case of adiponectin, leptin and endotrophin. High serum levels of adiponectin was inversely associated with lower BMI and waist circumference [146]. Furthermore, high level of adiponectin was significantly associated with lower risk of both colorectal adenoma and carcinoma [147]. Adiponectin (OR $=0.50$; CI: $0.3-0.8)$ and the soluble receptor for advanced glycation end products (sRAGE, OR $=0.4, \mathrm{CI}: 0.3-0.7$ ) were inversely related to the presence of diverticulosis [148].

Leptin, also called obese gene product, regulates body weight and fat deposition through effects on metabolism, and increases appetite $[149,150]$. Hyperleptinemia is characteristic of obese patients and leptin has been reported to promote colon carcinogenesis [151]. In fact, in vitro models of leptin stimulation showed not only increased proliferation of CRC cell lines [152] but also angiogenesis and production of other cytokines like IL-6 [153]. In humans patients, high leptin levels have been associated with higher risk to develop adenoma in obese individuals (BMI > 30) compared to lean individuals $(B M I<25)$ [154]. In contrast, other approaches suggest that leptin may be associated with risk of colorectal adenomas in men, however it does not correlate in women [155]. High leptin levels were also positively associated with diverticulosis (OR $=5.5, \mathrm{CI}$ : 2.0-14.7) [148]. Some genes that regulate the WNT- $\beta$-catenin pathway such as $M D M 2, P I K 3 R 1$, and $R B 1$ were upregulated by leptin. Importantly, leptin supplementation induced expression of IGF-mediated pathway genes and their products such as IGFBP-6, IGF1, and Crim1 [153]. On the contrary, other factors were downregulated like IGFBP-2, IGFBP3, IGFBP-4, IGFBP-5, and Nov [153].

Endotrophin is the result of cleaved form of $\mathrm{C} 5$ fragment of the collagen type VI alpha 3 chain (COL6A3) [156]. It seems that it acts as a signaling molecule modulating several effects in the tumour-stromal environment like epithelial-mesenchymal transition of cancer cells, fibrosis, angiogenesis and immune cell infiltrations [156], especially observed in breast cancer [157].

Thus, obesity changes the stability and homeostasis of adipocytes and produces different hormones and cytokines leading to inflammation, a process that joins obesity and CRC initiation and progression.

\section{Obesity and inflammation: a direct link with CRC}

Obesity is a state of low-grade chronic inflammation and is closed linked to cancer (Fig. 2) [158]. It is probably because the largest endocrine organ in the body is the adipose tissue and it stimulates secretion of several signaling cytokines. Some of the cytokines produced by adipose tissue are IL-8, IL-6, IL-2, lactate dehydrogenase (LDH), tumour necrosis factor alpha (TNF $\alpha)$, as well as IL-2 receptor alpha (IL-2ra) (Fig. 2). These cytokines have been reported to play a role not only in both tumour initiation and progression [159-161] but also in promoting epithelial mesenchymal transition and metastasis in obese patients [162,163].

For example, high levels of LDH, IL-2ra and IL-8 are considered poor prognostic factors in obese metastasic CRC patients [164]. Other cytokines like PDGF, TGF- $\beta$, FGF and VEGF have been found to be upregulated in the mammary-associated fat in humans [24].

IL-6 family of cytokines is highly upregulated in many cancers and it is considered as one of the most important cytokine families during tumourigenesis and metastasis [165]. Tumour necrosis factor alpha promote insulin resistance in the liver and other metabolism-controlling organs with the subsequent cancer promotion [24].

Also proinflammatory factors, like interferon gamma-inducible protein-10 (IP-10), function as chemo-attractant to enhance local inflammation [166]. Interestingly, IP-10 expression was significantly associated with increased likelihood to develop adenomas while TNF $\alpha$ showed a trend $(\mathrm{P}=0.09)$ [146]. 
On the other hand, when tumour is initiated it may arrest inflammation to escape of immune cells. One mechanism to assess this is by decreasing the inflammation signal of adipose tissue through the regulation of macrophages phenotype. Other cytokines are involved in such process like interferon gamma (IFN- $\gamma$ ) and IL-10 that are produced by tumour microenvironment [167]. This cytokines keep M2 polarization of macrophages and those with M1 phenotype are converted into M2 [168]. M2 macrophages are those activated under lean conditions [169] and associated to tumour progression [170]. Some B cells (B1) could also induce macrophages phenotypic change [171-173]. Moreover, in response to upregulation of IFN- $\gamma$ and IL-10, cells from tumour microenvironment like antigen presenting cells (APCs), tumour associated myeloid derived suppressor cells (MDSC), and M2 macrophages are able to produce indolamine 2,3-dioxygenase (IDO). This compound promotes anti-inflammatory phenotype by suppression of $\mathrm{T}$ and NK cell activity which enables immune escape of cancer, angiogenesis and metastasis [174-176].

\section{Discussion}

Over the past few decades, obesity has emerged as a global epidemic. A cross-sectional survey conducted in 2003-2004 revealed that $66.2 \%$ of United States adults who averaged 20-and-74 years old were either overweight or obese [177]. Nowadays, in the US more than $30 \%$ of the population is obese [1] and a thin line separates obesity and colorectal neoplasia. The most common ratio to classify individuals according anthropometric measures is BMI [178]. Wu et al. reported that obese patients appear to have worse overall survival than normal-weight patients with CRC [145]. Studies concerning chemotherapy resistance are rather controversial, on the one hand, it is showed an association between high BMI and VAT with reduced time-to-progression after receiving first-line anti-angiogenic therapy [179]. On the other, anthropometric measures are considered poor outcome markers since it reveals a nutritional impairment during chemotherapy administration [53, 54]. Other study associated BMI with CRC-related mortality in pre-diagnosis men [6] however BMI association with CRC outcome according to sexes is rather disputed. Therefore, the standard use of BMI as indicator of obesity may be examined. The National Health and Nutrition Examination Survey (NHANES) reported $>50 \%$ of individuals with high body fat content would be classified as being normal of just overweight [180]. It seems that correlation between cancer and BMI is far to be linear because not all obese patients might eventually develop colorectal cancer. However, a recent report highlights BMI as an independent predictor for overall survival dealing with overweight and obese patients with $\mathrm{mCRC}$ treated with Bevacizumab [181]. Additionally, the association of obesity with survival of CRC patients is likely to be affected by the timing of BMI measurement [182]. An obese prediagnostic measured by BMI months-years before presentation of CRC has been consistently linked to worse survival [6, 183]. All these results suggest that perhaps BMI has enough limitations to be considered as the best marker of obesity, particularly individuals in the intermediate BMI ranges, men and the elderly. Therefore, in the near future, find a marker to highlight obesity to tailor screening practices for CRC will be a challenge in this field.

There are several factors that influence weight gain but are mostly diet and physical activity. A diet based on different meats, poultry, fish and eggs was associated with a $50 \%$ increase in risk among men [184]. Moreover, it has been reported how high fat content diet, increase intestinal cancer in genetically susceptible mice [185]. By contrast, vegetable fiber intake has been demonstrated to offer a protective effect on CRC [186]. Thus, a dietary habits change becomes a crucial element to reduce potential risk.

The link between physical activity and cancer is controversial. Although it has been estimated in US that $13-14 \%$ of colon cancer may be attributable to physical inactivity [184], other reports showed body weigh loss was not enough to reduce cancer risk [187]. The lack of physical activity can lead to adipose tissue accumulation and the subsequent stimulation of inflammatory cytokines that could promote CRC [188].

Other crucial factor to consider is gut microbiota. Colonic tumours revealed enrichment in fusobacteria what has been visualized by FISH and detected by PCR $[189,190]$. Moreover, this kind of microorganisms have been related to those CRC carrying MSI, TP53 wildtype, CIMP positive, $M L H 1$ positive methylation status, and $C H D 7 / 8$ mutation positive [191]. Other authors demonstrate involvement of fusobacterium with highgrade dysplasia [190] and recently with poor prognosis CRC [192]. Fusobacterium also promotes downregulation of antitumour CD3 $+\mathrm{T}$ cell-mediated adaptive immunity [193].

Other factors play an essential role in hematopoietic and chemotactic functions to promote tumour initiation, growth and metastasis and may limit survival in patients with CRC [194-196]. Elevated levels of some inflammatory cytokines contributed to poor survival rates in mCRC, especially interleukin 8 (IL-8), and LDH [197]. The association between IL- 8 and LDH levels and risk of death is higher in obese mCRC patients than in nonobese mCRC patients. On the other hand, high levels of adiponectin present low-risk of CRC [198]. 
The chronic low-grade inflammation state produced by obesity leads the induction of oxidative stress factors. The major bioactive product of lipid peroxidation is 4-HNE and it is responsible of deregulation of multiple pathways involved in cell proliferation differentiation, cell survival, autophagy, senescence, apoptosis and necrosis. The molecular pathways mainly altered by 4-HNE includes MAPK, PIK3CA-AKT and NF- $\mathrm{BB}$, in addition to accelerating adiponectin degradation and upregulation of prostaglandin E2, all them related to CRC development. Moreover, accumulation of DNA mutations, as in $A P C$, $K R A S, N R A S, B R A F$, or PIK3CA, and insulin secretion sets obesity as a multifactor phenomenon involved in CRC initiation and aggressive development. These events may be fostered by MDA, the other bioreactive and mutagenic product of lipid metabolism. To dissect how outer effects affect transformation, initiation, and progression of CRC, a new field has emerged called "molecular pathologic epidemiology". This domain will provide future scientific explanations of tumorigenesis related to life style, diet and other environmental factors, in order to bring new prevention strategies [199, 200].

These facts point out the strong involvement between obesity and CRC, even if it seems to be higher for colon than for rectal neoplasias [201].

\section{Conclusions}

As we have seen, one of the main diseases in western countries is obesity. Over the last decade several studies found a close connection between obesity and development of colorectal neoplasias. Then, biochemical studies revealed that oxidative stress conducted by lipid peroxidation produce secondary metabolites with highly mutagenic and toxic properties. These products lead the initiation of pathological disorders by accumulation of genomic aberrations. Development of CRC and evolution to malignant phenotype is allowed by accumulation of additional genomic aberrations that may be assisted by these high mutagenic products. Therefore, obesity performs a complex biological activity regulation like cytokines production leading insulin resistance or deregulation of IGF1 and immune system among others. Then, obesity must be diagnosed and controlled not only to prevent comorbidities like high blood pressure, high levels of triglycerides, cholesterol or elevated fasting plasma glucose, but also obesity must be considered as an early warning for a potential pre-neoplasic lesions.

\footnotetext{
Abbreviations

APCs: antigen presenting cells; AP-1: activating protein-1; BAX: BCL2-associated $X$ protein; CTNNB1: $\beta$-catenin; BIA: bioelectrical impedance analysis; BMI: body mass index; CIN: chromosomal instability; COL6A3: collagen type VI alpha 3; CRC: colorectal cancer; CT: computerized tomography; CIMP: CpG island methylator phenotype; EGFR: epidermal growth factor receptor; FISH:
}

fluorescent in situ hybridization; HR: hazard ratio; 4-HNE: 4-hydroxy-2-nonenal; IL-2ra: IL-2 receptor alpha; IDO: indolamine 2,3-dioxygenase; IGF1: insulin growth factor 1 ; IFN-ץ: interferon gamma; IP-10: interferon gamma-inducible protein-10; LDH: lactate dehydrogenase; MDA: malondialdehyde; mCRC: metastatic colorectal cancer; MTHFR: methylenetetrahydrofolate reductase; MSI: microsatellite instability; MMR: mismatch-repair deficiency; MAPK: mitogen-activated protein kinase; OR: odds ratio; PPAR: peroxisome-proliferator-activated receptors; PIK3CA: phosphoinositide 3-kinase; PKC: protein kinase C; M1-dG: Pyrimido(1,2-a)purin-10(3H-)one; sRAGE: soluble receptor for advanced glycation end products; $S / T$ ratio: skinfold thickness; TGFBR2: transforming growth factor $\beta$ (TGF- $\beta$ ) receptor type II; MDSC: tumour associated myeloid derived suppressor cells; TNF-a: tumour necrosis factor; VAT: visceral adipose tissue; WHR: waist-to-hip.

\section{Authors' contributions}

$J \mathrm{M}-\mathrm{U}$ : have made the substantial contribution in designing, updating current literature and writing the review. JG-F: contributed in table designing, and guideance in this review writing. Both authors read and approved the final manuscript.

\section{Acknowledgements}

The authors wish to thank Ana Martin for valuable assistance during the preparation of this review. This work has been carried out with the support of the RNA-Reg. CONSOLIDER-Consortium (CSD2009-00080) of the Spanish Ministry of Economy and Competitiveness.

\section{Competing interests}

The authors declare that they have no competing interests.

Received: 20 October 2015 Accepted: 5 January 2016

Published online: 22 January 2016

\section{References}

1. Ogden CL, Carroll MD, Kit BK, Flegal KM. Prevalence of childhood and adult obesity in the United States, 2011-2012. JAMA. 2014;311(8):806-14.

2. Parkin DM, Boyd L, Walker LC. 16. The fraction of cancer attributable to lifestyle and environmental factors in the UK in 2010. Br J Cancer. 2011;2011(6):489.

3. Chan DS, Vieira AR, Aune D, Bandera EV, Greenwood DC, McTiernan $A$, et al. Body mass index and survival in women with breast cancersystematic literature review and meta-analysis of 82 follow-up studies. Ann Oncol. 2014;25(10):1901-14.

4. Arem H, Chlebowski R, Stefanick ML, Anderson G, Wactawski-Wende J, Sims S, et al. Body mass index, physical activity, and survival after endometrial cancer diagnosis: results from the Women's Health Initiative. Gynecol Oncol. 2013;128(2):181-6.

5. Leung C, Yeoh SW, Patrick D, Ket S, Marion K, Gow P, et al. Characteristics of hepatocellular carcinoma in cirrhotic and non-cirrhotic non-alcoholic fatty liver disease. World J Gastroenterol. 2015;21(4):1189-96.

6. Parkin E, O'Reilly DA, Sherlock DJ, Manoharan P, Renehan AG. Excess adiposity and survival in patients with colorectal cancer: a systematic review. Obes Rev. 2014;15(5):434-51.

7. Siegel RL, Miller KD, Jemal A. Cancer statistics, 2015. CA Cancer J Clin. 2015;65(1):5-29. doi:10.3322/caac.21254.

8. Chan DS, Lau R, Aune D, Vieira R, Greenwood DC, Kampman E, et al. Red and processed meat and colorectal cancer incidence: meta-analysis of prospective studies. PLoS One. 2011;6(6):6.

9. Meyerhardt JA, Sato K, Niedzwiecki D, Ye C, Saltz LB, Mayer RJ, et al. Dietary glycemic load and cancer recurrence and survival in patients with stage III colon cancer: findings from CALGB 89803. J Natl Cancer Inst. 2012;104(22):1702-11.

10. Fuchs MA, Sato K, Niedzwiecki D, Ye X, Saltz LB, Mayer RJ, et al. Sugarsweetened beverage intake and cancer recurrence and survival in CALGB 89803 (Alliance). PLoS One. 2014;9(6):2014.

11. Rosati $\mathrm{R}, \mathrm{Ma} \mathrm{H}$, Cabelof DC. Folate and colorectal cancer in rodents: $a$ model of DNA repair deficiency. J Oncol. 2012;2012(105949):9. 
12. Leclerc D, Dejgaard K, Mazur A, Deng L, Wu Q, Nilsson T, et al. Quantitative proteomics reveals differentially expressed proteins in murine preneoplastic intestine in a model of intestinal tumourigenesis induced by low dietary folate and MTHFR deficiency. Proteomics. 2014;14(21-22):2558-65.

13. Koshy G, Delpisheh A, Brabin BJ. Dose response association of pregnancy cigarette smoke exposure, childhood stature, overweight and obesity. Eur J Public Health. 2011;21(3):286-91.

14. Cupul-Uicab LA, Skjaerven R, Haug K, Melve KK, Engel SM, Longnecker MP. In utero exposure to maternal tobacco smoke and subsequent obesity, hypertension, and gestational diabetes among women in the MoBa cohort. Environ Health Perspect. 2012;120(3):355-60.

15. Kim HW, Kam S, Lee DH. Synergistic interaction between polycyclic aromatic hydrocarbons and environmental tobacco smoke on the risk of obesity in children and adolescents: the U.S. National Health and Nutrition Examination Survey 2003-2008. Environ Res. 2014;135:354-60.

16. Yang CM, Lee IT, Lin CC, Yang YL, Luo SF, Kou YR, et al. Cigarette smoke extract induces COX-2 expression via a PKCalpha/c-Src/EGFR, PDGFR/ $\mathrm{PI3}$ K/Akt/NF-kappaB pathway and p300 in tracheal smooth muscle cells. Am J Physiol Lung Cell Mol Physiol. 2009;297(5):28.

17. Pai R, Soreghan B, Szabo IL, Pavelka M, Baatar D, Tarnawski AS. Prostaglandin E2 transactivates EGF receptor: a novel mechanism for promoting colon cancer growth and gastrointestinal hypertrophy. Nat Med. 2002;8(3):289-93.

18. Castellone MD, Teramoto H, Williams BO, Druey KM, Gutkind JS. Prostaglandin E2 promotes colon cancer cell growth through a Gs-axin-betacatenin signaling axis. Science. 2005;310(5753):1504-10.

19. Martinez ME, Heddens D, Earnest DL, Bogert CL, Roe D, Einspahr J, et a Physical activity, body mass index, and prostaglandin E2 levels in rectal mucosa. J Natl Cancer Inst. 1999;91(11):950-3.

20. Kuchiba A, Morikawa T, Yamauchi M, Imamura Y, Liao X, Chan AT, et al. Body mass index and risk of colorectal cancer according to fatty acid synthase expression in the nurses' health study. J Natl Cancer Inst. 2012;104(5):415-20.

21. Morikawa T, Kuchiba A, Lochhead P, Nishihara R, Yamauchi M, Imamura $Y$, et al. Prospective analysis of body mass index, physical activity, and colorectal cancer risk associated with beta-catenin (CTNNB1) status. Cancer Res. 2013;73(5):1600-10.

22. Tandon K, Imam M, Ismail BE, Castro F. Body mass index and colon cancer screening: the road ahead. World J Gastroenterol. 2015;21(5):13716. doi:10.3748/wjg.v21.i5.1371

23. Olefsky JM, Glass CK. Macrophages, inflammation, and insulin resistance. Annu Rev Physiol. 2010;72:219-46.

24. Mirza RE, Koh TJ. Contributions of cell subsets to cytokine production during normal and impaired wound healing. Cytokine. 2015;71(2):409-12.

25. Karin M, Greten FR. NF-kappaB: linking inflammation and immunity to cancer development and progression. Nat Rev Immunol. 2005;5(10):749-59.

26. Ashwell M, Gunn P, Gibson S. Waist-to-height ratio is a better screening tool than waist circumference and BMI for adult cardiometabolic risk factors: systematic review and meta-analysis. Obes Rev. 2012;13(3):275-86

27. Schneider HJ, Friedrich N, Klotsche J, Pieper L, Nauck M, John U, et al. The predictive value of different measures of obesity for incident cardiovascular events and mortality. J Clin Endocrinol Metab. 2010;95(4):1777-85.

28. DGSP. S 1-Leitlinie Vorsorgeuntersuchung im Sport. 2007.

29. Song M, Hu FB, Spiegelman D, Chan AT, Wu K, Ogino S, et al. Long-term status and change of body fat distribution, and risk of colorectal cancer: a prospective cohort study. Int J Epidemiol. 2015. doi:10.1093/ije/dyv177.

30. Volgyi E, Tylavsky FA, Lyytikainen A, Suominen H, Alen M, Cheng S. Assessing body composition with DXA and bioimpedance: effects of obesity, physical activity, and age. Obesity. 2008;16(3):700-5.

31. Amato MC, Giordano C. Visceral adiposity index: an indicator of adipose tissue dysfunction. Int J Endocrinol. 2014;2014(730827):14.

32. Choe EK, Kim D, Kim HJ, Park KJ. Association of visceral obesity and early colorectal neoplasia. World J Gastroenterol. 2013;19(45):8349-56.

33. Park SW, Lee HL, Doo EY, Lee KN, Jun DW, Lee OY, et al. Visceral obesity predicts fewer lymph node metastases and better overall survival in colon cancer. J Gastrointest Surg. 2015;19(8):1513-21.
34. Fujioka S, Matsuzawa Y, Tokunaga K, Tarui S. Contribution of intraabdominal fat accumulation to the impairment of glucose and lipid metabolism in human obesity. Metabolism. 1987;36(1):54-9.

35. Malietzis G, Aziz O, Bagnall NM, Johns N, Fearon KC, Jenkins JT. The role of body composition evaluation by computerized tomography in determining colorectal cancer treatment outcomes: a systematic review. Eur J Surg Oncol. 2015;41(2):186-96.

36. Kang SM, Yoon JW, Ahn HY, Kim SY, Lee KH, Shin H, et al. Android fat depot is more closely associated with metabolic syndrome than abdominal visceral fat in elderly people. PLoS One. 2011;6(11):11.

37. Fox CS, Massaro JM, Hoffmann U, Pou KM, Maurovich-Horvat P, Liu CY, et al. Abdominal visceral and subcutaneous adipose tissue compartments: association with metabolic risk factors in the Framingham Heart Study. Circulation. 2007;116(1):39-48.

38. WHO_Expert_Committee. Physical status: the use and interpretation of anthropometry. Report of a WHO Expert Committee. Geneva: World Health Organization Technical Report Series; 1995.

39. Murphy TK, Calle EE, Rodriguez C, Kahn HS, Thun MJ. Body mass index and colon cancer mortality in a large prospective study. Am J Epidemiol. 2000;152(9):847-54.

40. Graham S, Marshall J, Haughey B, Mittelman A, Swanson M, Zielezny M, et al. Dietary epidemiology of cancer of the colon in western New York. Am J Epidemiol. 1988;128(3):490-503.

41. de Verdier MG, Hagman U, Steineck G, Rieger A, Norell SE. Diet, body mass and colorectal cancer: a case-referent study in Stockholm. Int J Cancer. 1990;46(5):832-8.

42. Kune GA, Kune S, Watson LF. Body weight and physical activity as predictors of colorectal cancer risk. Nutr Cancer. 1990;13(1-2):9-17.

43. Le Marchand L, Wilkens LR, Kolonel LN, Hankin JH, Lyu LC. Associations of sedentary lifestyle, obesity, smoking, alcohol use, and diabetes with the risk of colorectal cancer. Cancer Res. 1997;57(21):4787-94.

44. Caan BJ, Coates AO, Slattery ML, Potter JD, Quesenberry CP Jr, Edwards $\mathrm{SM}$. Body size and the risk of colon cancer in a large case-control study. Int J Obes Relat Metab Disord. 1998;22(2):178-84.

45. Russo A, Franceschi S, La Vecchia C, Dal Maso L, Montella M, Conti E, et al. Body size and colorectal-cancer risk. Int J Cancer. 1998;78(2):161-5.

46. Zhang X, Wu K, Giovannucci EL, Ma J, Colditz GA, Fuchs CS, et al. Early life body fatness and risk of colorectal cancer in US Women and menresults from two large cohort studies. Cancer Epidemiol Biomark Prev. 2015;24(4):690-7.

47. Dietz AT, Newcomb PA, Marcus PM, Storer BE. The association of body size and large bowel cancer risk in Wisconsin (United States) women. Cancer Causes Control. 1995;6(1):30-6.

48. Ashktorab H, Paydar M, Yazdi S, Namin HH, Sanderson A, Begum R, et al. $\mathrm{BMI}$ and the risk of colorectal adenoma in African-Americans. Obesity. 2014;22(5):1387-91.

49. Nagata N, Sakamoto K, Arai T, Niikura R, Shimbo T, Shinozaki M, et al. Visceral abdominal fat measured by computed tomography is associated with an increased risk of colorectal adenoma. Int J Cancer. 2014;135(10):2273-81.

50. Liesenfeld DB, Grapov D, Fahrmann JF, Salou M, Scherer D, Toth R, et al. Metabolomics and transcriptomics identify pathway differences between visceral and subcutaneous adipose tissue in colorectal cancer patients: the ColoCare study. Am J Clin Nutr. 2015;102(2):433-43.

51. Schoen RE, Weissfeld JL, Kuller LH, Thaete FL, Evans RW, Hayes RB, et al. Insulin-like growth factor-I and insulin are associated with the presence and advancement of adenomatous polyps. Gastroenterology. 2005;129(2):464-75.

52. Lee CS, Murphy DJ, McMahon C, Nolan B, Cullen G, Mulcahy H, et al. Visceral adiposity is a risk factor for poor prognosis in colorectal cancer patients receiving adjuvant chemotherapy. J Gastrointest Cancer. 2015;46(3):243-50.

53. Santarpia L, Contaldo F, Pasanisi F. Nutritional screening and early treatment of malnutrition in cancer patients. J Cachexia Sarcopenia Muscle. 2011;2(1):27-35.

54. Bozzetti F. Nutritional support of the oncology patient. Crit Rev Oncol Hematol. 2013;87(2):172-200.

55. Thrift AP, Gong J, Peters U, Chang-Claude J, Rudolph A, Slattery ML, et al. Mendelian randomization study of body mass index and colorectal cancer risk. Cancer Epidemiol Biomark Prev. 2015;2015:14. 
56. Yin $\mathrm{H}, \mathrm{Xu} \mathrm{L}$, Porter NA. Free radical lipid peroxidation: mechanisms and analysis. Chem Rev. 2011;111(10):5944-72.

57. Kinnunen PK, Kaarniranta K, Mahalka AK. Protein-oxidized phospholipid interactions in cellular signaling for cell death: from biophysics to clinical correlations. Biochim Biophys Acta. 2012;2012(10):2446-55.

58. Fruhwirth GO, Loidl A, Hermetter A. Oxidized phospholipids: from molecular properties to disease. Biochim Biophys Acta. 2007;7:718-36.

59. Esterbauer $\mathrm{H}$, Eckl P, Ortner A. Possible mutagens derived from lipids and lipid precursors. Mutat Res. 1990;238(3):223-33.

60. Brambilla G, Sciaba L, Faggin P, Maura A, Marinari UM, Ferro M, et al. Cytotoxicity, DNA fragmentation and sister-chromatid exchange in Chinese hamster ovary cells exposed to the lipid peroxidation product 4-hydroxynonenal and homologous aldehydes. Mutat Res. 1986;171(2-3):169-76

61. Zarkovic N. 4-hydroxynonenal as a bioactive marker of pathophysiological processes. Mol Aspects Med. 2003;24(4-5):281-91.

62. Shaulian E. AP-1-The Jun proteins: oncogenes or tumour suppressors in disguise? Cell Signal. 2010;22(6):894-9.

63. Morgan MJ, Liu ZG. Crosstalk of reactive oxygen species and NF-kappaB signaling. Cell Res. 2011;21(1):103-15.

64. Ahmadian M, Suh JM, Hah N, Liddle C, Atkins AR, Downes M, et al. PPARgamma signaling and metabolism: the good, the bad and the future. Nat Med. 2013;19(5):557-66.

65. Wang Z, Dou X, Gu D, Shen C, Yao T, Nguyen V, et al. 4-Hydroxynonenal differentially regulates adiponectin gene expression and secretion via activating PPARgamma and accelerating ubiquitin-proteasome degradation. Mol Cell Endocrinol. 2012;349(2):222-31.

66. Shu L, Huang R, Wu S, Chen Z, Sun K, Jiang Y, et al. PPAR gamma and its ligands, potential anti-tumour agents in the digestive system. Curr Stem Cell Res Ther. 2015;2015:30.

67. Kwon KA, Yun J, Oh SY, Seo BG, Lee S, Lee JH, et al. Clinical significance of peroxisome proliferator-activated Receptor gamma and TRAP220 in patients with operable colorectal cancer. Cancer Res Treat. 2015;2015(23):024

68. Pang T, Kaufman A, Choi J, Gill A, Drummond M, Hugh T, et al. Peroxisome proliferator-activated receptor-alpha staining is associated with worse outcome in colorectal liver metastases. Mol Clin Oncol. 2015;3(2):308-16.

69. Shi Q, Vaillancourt F, Cote V, Fahmi H, Lavigne P, Afif H, et al. Alterations of metabolic activity in human osteoarthritic osteoblasts by lipid peroxidation end product 4-hydroxynonenal. Arthritis Res Ther. 2006;8(6):R159.

70. Uchida K, Kumagai T. 4-hydroxy-2-nonenal as a COX-2 inducer. Mol Aspects Med. 2003;24(4-5):213-8.

71. Kaidi A, Qualtrough D, Williams AC, Paraskeva C. Direct transcriptional up-regulation of cyclooxygenase-2 by hypoxia-inducible factor (HIF)-1 promotes colorectal tumour cell survival and enhances HIF-1 transcriptional activity during hypoxia. Cancer Res. 2006;66(13):6683-91.

72. Sanchez-de-Abajo A, de la Hoya M, van Puijenbroek M, Tosar A, LopezAsenjo JA, Diaz-Rubio E, et al. Molecular analysis of colorectal cancer tumours from patients with mismatch repair proficient hereditary nonpolyposis colorectal cancer suggests novel carcinogenic pathways. Clin Cancer Res. 2007;13(19):5729-35.

73. Slattery ML, Lundgreen A, Wolff RK. MAP kinase genes and colon and rectal cancer. Carcinogenesis. 2012;33(12):2398-408.

74. Luo F, Poulogiannis G, Ye H, Hamoudi R, Zhang W, Dong G, et al. Mutant K-ras promotes carcinogen-induced murine colorectal tumourigenesis, but does not alter tumour chromosome stability. J Pathol. 2011;223(3):390-9.

75. Cantwell-Dorris ER, O'Leary JJ, Sheils OM. BRAFV600E: implications for carcinogenesis and molecular therapy. Mol Cancer Ther. 2011;10(3):385-94.

76. Chalhoub N, Baker SJ. PTEN and the PI3-kinase pathway in cancer. Annu Rev Pathol. 2009;4:127-50.

77. Sahin IH, Oktay AA. EGFR signaling and oncogenic pathway signature in colorectal cancer. Gut. 2013;62(11):1670. doi:10.1136/ gutjnl-2013-304781 (Epub 2013).

78. Paola D, Domenicotti C, Nitti M, Vitali A, Borghi R, Cottalasso D, et al. Oxidative stress induces increase in intracellular amyloid beta-protein production and selective activation of betal and betall PKCs in NT2 cells. Biochem Biophys Res Commun. 2000;268(2):642-6.
79. Cooke MS, Evans MD, Dizdaroglu M, Lunec J. Oxidative DNA damage: mechanisms, mutation, and disease. Faseb J. 2003;17(10):1195-214.

80. Savio M, Stivala LA, Bianchi L, Vannini V, Prosperi E. Involvement of the proliferating cell nuclear antigen (PCNA) in DNA repair induced by alkylating agents and oxidative damage in human fibroblasts. Carcinogenesis. 1998;19(4):591-6.

81. Barcelos RC, Vey LT, Segat HJ, Roversi K, Dias VT, Trevizol F, et al. Crossgenerational trans fat intake exacerbates UV radiation-induced damage in rat skin. Food Chem Toxicol. 2014:69:38-45.

82. Murray AR, Kisin E, Castranova V, Kommineni C, Gunther MR, Shvedova AA. Phenol-induced in vivo oxidative stress in skin: evidence for enhanced free radical generation, thiol oxidation, and antioxidant depletion. Chem Res Toxicol. 2007;20(12):1769-77.

83. Pongnimitprasert N, Hurtado M, Lamari F, El Benna J, Dupuy C, Fay $\mathrm{M}$, et al. Implication of NADPH oxidases in the early inflammation process generated by cystic fibrosis cells. ISRN Inflamm. 2012;2012(481432):2012

84. Niedernhofer LJ, Daniels JS, Rouzer CA, Greene RE, Marnett LJ. Malondialdehyde, a product of lipid peroxidation, is mutagenic in human cells. $J$ Biol Chem. 2003;278(33):31426-33.

85. Wang M, Dhingra K, Hittelman WN, Liehr JG, de Andrade M, Li D. Lipid peroxidation-induced putative malondialdehyde-DNA adducts in human breast tissues. Cancer Epidemiol Biomark Prev. 1996;5(9):705-10.

86. Wang $X$, Lei $X G$, Wang J. Malondialdehyde regulates glucose-stimulated insulin secretion in murine islets via TCF7L2-dependent Wnt signaling pathway. Mol Cell Endocrinol. 2014;382(1):8-16.

87. Blair IA. DNA adducts with lipid peroxidation products. J Biol Chem. 2008:283(23):15545-9.

88. Garcia SC, Grotto D, Bulcao RP, Moro AM, Roehrs M, Valentini J, et al. Evaluation of lipid damage related to pathological and physiological conditions. Drug Chem Toxicol. 2013;36(3):306-12.

89. Shanmugam N, Figarola JL, Li Y, Swiderski PM, Rahbar S, Natarajan R. Proinflammatory effects of advanced lipoxidation end products in monocytes. Diabetes. 2008;57(4):879-88.

90. Merendino RA, Salvo F, Saija A, Di Pasquale G, Tomaino A, Minciullo $\mathrm{PL}$, et al. Malondialdehyde in benign prostate hypertrophy: a useful marker? Mediators Inflamm. 2003;12(2):127-8.

91. Bartoli ML, Novelli F, Costa F, Malagrino L, Melosini L, Bacci E, et al. Malondialdehyde in exhaled breath condensate as a marker of oxidative stress in different pulmonary diseases. Mediators Inflamm. 2011;2011(891752):16

92. Marnett LJ. Oxy radicals, lipid peroxidation and DNA damage. Toxicology. 2002;182:219-22.

93. Sram RJ, Farmer P, Singh R, Garte S, Kalina I, Popov TA, et al. Effect of vitamin levels on biomarkers of exposure and oxidative damage-the EXPAH study. Mutat Res. 2009;672(2):129-34.

94. Vogelstein B, Fearon ER, Hamilton SR, Kern SE, Preisinger AC, Leppert $\mathrm{M}$, et al. Genetic alterations during colorectal-tumour development. N Engl J Med. 1988;319(9):525-32.

95. Rex DK, Ahnen DJ, Baron JA, Batts KP, Burke CA, Burt RW, et al. Serrated lesions of the colorectum: review and recommendations from an expert panel. Am J Gastroenterol. 2012;107(9):1315-29.

96. Colussi D, Brandi G, Bazzoli F, Ricciardiello L. Molecular pathways involved in colorectal cancer: implications for disease behavior and prevention. Int J Mol Sci. 2013;14(8):16365-85.

97. Fearon ER BG. Molecular biology of colorectal cancer. In: DeVita VT Jr LT, Rosenberg SA, editors. De- Vita, Hellman, and Rosenberg's cancer: principles \& practice of oncology. Philadelphia: Lippincott Williams \& Wilkins; 2008.

98. Xu K, Shu HK. EGFR activation results in enhanced cyclooxygenase-2 expression through p38 mitogen-activated protein kinase-dependent activation of the Sp1/Sp3 transcription factors in human gliomas. Cancer Res. 2007;67(13):6121-9.

99. Cha YI, DuBois RN. NSAIDs and cancer prevention: targets downstream of COX-2. Annu Rev Med. 2007;58:239-52.

100. Wang D, Fu L, Sun H, Guo L, DuBois RN. Prostaglandin E promotes colorectal cancer stem cell expansion and metastasis in mice. Gastroenterology. 2015;149(7):1884-95.

101. Fearon ER, Vogelstein B. A genetic model for colorectal tumourigenesis. Cell. 1990;61(5):759-67. 
102. Lynch HT, Lynch JF, Lynch PM, Attard T. Hereditary colorectal cancer syndromes: molecular genetics, genetic counseling, diagnosis and management. Fam Cancer. 2008;7(1):27-39.

103. Goss KH, Groden J. Biology of the adenomatous polyposis coli tumour suppressor. J Clin Oncol. 2000;18(9):1967-79.

104. Newton K, Jorgensen NM, Wallace AJ, Buchanan DD, Lalloo F, McMahon $\mathrm{RF}$, et al. Tumour MLH1 promoter region methylation testing is an effective prescreen for Lynch Syndrome (HNPCC). J Med Genet. 2014;51(12):789-96

105. Papadopoulos N, Nicolaides NC, Wei YF, Ruben SM, Carter KC, Rosen CA, et al. Mutation of a mutL homolog in hereditary colon cancer. Science. 1994;263(5153):1625-9.

106. Bronner CE, Baker SM, Morrison PT, Warren G, Smith LG, Lescoe MK, et al. Mutation in the DNA mismatch repair gene homologue hMLH1 is associated with hereditary non-polyposis colon cancer. Nature. 1994;368(6468):258-61.

107. Fujiwara T, Stolker JM, Watanabe T, Rashid A, Longo P, Eshleman JR, et al. Accumulated clonal genetic alterations in familial and sporadic colorectal carcinomas with widespread instability in microsatellite sequences. Am J Pathol. 1998;153(4):1063-78.

108. Poulogiannis G, Frayling IM, Arends MJ. DNA mismatch repair deficiency in sporadic colorectal cancer and Lynch syndrome. Histopathology. 2010;56(2):167-79.

109. Ji HP, King MC. A functional assay for mutations in tumour suppressor genes caused by mismatch repair deficiency. Hum Mol Genet. 2001;10(24):2737-43.

110. Baker SJ, Preisinger AC, Jessup JM, Paraskeva C, Markowitz S, Willson JK, et al. p53 gene mutations occur in combination with 17p allelic deletions as late events in colorectal tumourigenesis. Cancer Res. 1990;50(23):7717-22.

111. Ionov Y, Yamamoto H, Krajewski S, Reed JC, Perucho M. Mutational inactivation of the proapoptotic gene BAX confers selective advantage during tumour clonal evolution. Proc Natl Acad Sci USA. 2000;97(20):10872-7.

112. Trojan J, Brieger A, Raedle J, Weber N, Kriener S, Kronenberger B, et al. BAX and caspase- 5 frameshift mutations and spontaneous apoptosis in colorectal cancer with microsatellite instability. Int J Colorectal Dis. 2004;19(6):538-44.

113. Mrozek A, Petrowsky H, Sturm I, Kraus J, Hermann S, Hauptmann S, et al. Combined p53/Bax mutation results in extremely poor prognosis in gastric carcinoma with low microsatellite instability. Cell Death Differ. 2003;10(4):461-7.

114. Veigl ML, Kasturi L, Olechnowicz J, Ma AH, Lutterbaugh JD, Periyasamy $\mathrm{S}$, et al. Biallelic inactivation of hMLH1 by epigenetic gene silencing, a novel mechanism causing human MSI cancers. Proc Natl Acad Sci USA. 1998;95(15):8698-702

115. Slattery ML, Curtin K, Anderson K, Ma KN, Ballard L, Edwards S, et al. Associations between cigarette smoking, lifestyle factors, and microsatellite instability in colon tumours. J Natl Cancer Inst. 2000;92(22):1831-6.

116. Satia JA, Keku T, Galanko JA, Martin C, Doctolero RT, Tajima A, et al. Diet, lifestyle, and genomic instability in the North Carolina Colon Cancer Study. Cancer Epidemiol Biomark Prev. 2005;14(2):429-36.

117. Campbell PT, Jacobs ET, Ulrich CM, Figueiredo JC, Poynter JN, McLaughlin JR, et al. Case-control study of overweight, obesity, and colorectal cancer risk, overall and by tumour microsatellite instability status. J Natl Cancer Inst. 2010;102(6):391-400.

118. Bos JL, Fearon ER, Hamilton SR, Verlaan-de Vries M, van Boom JH, van der Eb AJ, et al. Prevalence of ras gene mutations in human colorectal cancers. Nature. 1987;327(6120):293-7.

119. Davies H, Bignell GR, Cox C, Stephens P, Edkins S, Clegg S, et al. Mutations of the BRAF gene in human cancer. Nature. 2002;417(6892):949-54.

120. Rajagopalan $\mathrm{H}$, Bardelli A, Lengauer C, Kinzler KW, Vogelstein B, Velculescu VE. Tumourigenesis: RAF/RAS oncogenes and mismatch-repair status. Nature. 2002;418(6901):934.

121. Brandstedt J, Wangefjord S, Nodin B, Eberhard J, Sundstrom M, Manjer J, et al. Associations of anthropometric factors with KRAS and BRAF mutation status of primary colorectal cancer in men and women: a cohort study. PLoS One. 2014;9(2):2014.
122. Samuels Y, Wang Z, Bardelli A, Silliman N, Ptak J, Szabo S, et al. High frequency of mutations of the PIK3CA gene in human cancers. Science. 2004;304(5670):11.

123. Lin PC, Lin JK, Lin HH, Lan YT, Lin CC, Yang SH, et al. A comprehensive analysis of phosphatase and tensin homolog deleted on chromosome 10 (PTEN) loss in colorectal cancer. World J Surg Oncol. 2015;13(1):015-0601.

124. Yin Y, Shen WH. PTEN: a new guardian of the genome. Oncogene. 2008;27(41):5443-53.

125. Therkildsen C, Bergmann TK, Henrichsen-Schnack T, Ladelund S, Nilbert $M$. The predictive value of KRAS, NRAS, BRAF, PIK3CA and PTEN for antiEGFR treatment in metastatic colorectal cancer: a systematic review and meta-analysis. Acta Oncol. 2014;53(7):852-64

126. Alliot C. Relevance of EGFR expression in colorectal cancer. Ann Oncol. 2005;16(9):1557-8 (author reply 1558-9. Epub 2005 May 3; 2005)

127. Spano JP, Lagorce C, Atlan D, Milano G, Domont J, Benamouzig R, et al. Impact of EGFR expression on colorectal cancer patient prognosis and survival. Ann Oncol. 2005;16(1):102-8.

128. She QB, Solit DB, Ye Q, O'Reilly KE, Lobo J, Rosen N. The BAD protein integrates survival signaling by EGFR/MAPK and PI3 K/ Akt kinase pathways in PTEN-deficient tumour cells. Cancer Cell. 2005;8(4):287-97.

129. Khandekar MJ, Cohen P, Spiegelman BM. Molecular mechanisms of cancer development in obesity. Nat Rev Cancer. 2011;11(12):886-95.

130. Cleary MP, Grossmann ME. Minireview: obesity and breast cancer: the estrogen connection. Endocrinology. 2009;150(6):2537-42.

131. Simpson ER. Aromatase: biologic relevance of tissue-specific expression. Semin Reprod Med. 2004;22(1):11-23.

132. Tchernof A, Mansour MF, Pelletier M, Boulet MM, Nadeau M, Luu-The V. Updated survey of the steroid-converting enzymes in human adipose tissues. J Steroid Biochem Mol Biol. 2015;147:56-69.

133. Pollak $M$. The insulin and insulin-like growth factor receptor family in neoplasia: an update. Nat Rev Cancer. 2012;12(3):159-69.

134. Renehan AG, Frystyk J, Flyvbjerg A. Obesity and cancer risk: the role of the insulin-IGF axis. Trends Endocrinol Metab. 2006;17(8):328-36.

135. Schoen RE, Tangen CM, Kuller LH, Burke GL, Cushman M, Tracy RP, et al. Increased blood glucose and insulin, body size, and incident colorectal cancer. J Natl Cancer Inst. 1999;91(13):1147-54.

136. Giovannucci E. Insulin and colon cancer. Cancer Causes Control. 1995:6(2):164-79.

137. Volkova E, Robinson BA, Willis J, Currie MJ, Dachs GU. Marginal effects of glucose, insulin and insulin-like growth factor on chemotherapy response in endothelial and colorectal cancer cells. Oncol Lett. 2014;7(2):311-20

138. Lahm H, Suardet L, Laurent PL, Fischer JR, Ceyhan A, Givel JC, et al. Growth regulation and co-stimulation of human colorectal cancer cell lines by insulin-like growth factor I, II and transforming growth factor alpha. Br J Cancer. 1992;65(3):341-6.

139. Tricoli JV, Rall LB, Karakousis CP, Herrera L, Petrelli NJ, Bell Gl, et al. Enhanced levels of insulin-like growth factor messenger RNA in human colon carcinomas and liposarcomas. Cancer Res. 1986;46(12 Pt 1):6169-73.

140. Remacle-Bonnet MM, Garrouste FL, Heller S, Andre F, Marvaldi JL, Pommier GJ. Insulin-like growth factor-I protects colon cancer cells from death factor-induced apoptosis by potentiating tumour necrosis factor alpha-induced mitogen-activated protein kinase and nuclear factor kappaB signaling pathways. Cancer Res. 2000;60(7):2007-17.

141. Guo YS, Jin GF, Houston CW, Thompson JC, Townsend CM Jr. Insulin-like growth factor-I promotes multidrug resistance in MCLM colon cancer cells. J Cell Physiol. 1998;175(2):141-8.

142. Koenuma M, Yamori T, Tsuruo T. Insulin and insulin-like growth factor 1 stimulate proliferation of metastatic variants of colon carcinoma 26. Jpn J Cancer Res. 1989;80(1):51-8.

143. Bjorndahl M, Cao R, Nissen LJ, Clasper S, Johnson LA, Xue Y, et al. Insulin-like growth factors 1 and 2 induce lymphangiogenesis in vivo. Proc Natl Acad Sci USA. 2005;102(43):15593-8.

144. Sekharam M, Zhao H, Sun M, Fang Q, Zhang Q, Yuan Z, et al. Insulin-like growth factor 1 receptor enhances invasion and induces resistance to apoptosis of colon cancer cells through the $\mathrm{Akt} / \mathrm{Bcl}-\mathrm{x}(\mathrm{L})$ pathway. Cancer Res. 2003;63(22):7708-16. 
145. Wu Y, Yakar S, Zhao L, Hennighausen L, LeRoith D. Circulating insulinlike growth factor-I levels regulate colon cancer growth and metastasis. Cancer Res. 2002;62(4):1030-5.

146. Comstock SS, Hortos K, Kovan B, McCaskey S, Pathak DR, Fenton الـ Adipokines and obesity are associated with colorectal polyps in adult males: a cross-sectional study. PLoS One. 2014;9(1):e85939.

147. Yamaji T, Iwasaki M, Sasazuki S, Tsugane S. Interaction between adiponectin and leptin influences the risk of colorectal adenoma. Cancer Res. 2010;70(13):5430-7.

148. Comstock SS, Lewis MM, Pathak DR, Hortos K, Kovan B, Fenton J. Crosssectional analysis of obesity and serum analytes in males identifies SRAGE as a novel biomarker inversely associated with diverticulosis. PLoS One. 2014;9(4):e95232.

149. Pelleymounter MA, Cullen MJ, Baker MB, Hecht R, Winters D, Boone T, et al. Effects of the obese gene product on body weight regulation in ob/ob mice. Science. 1995;269(5223):540-3.

150. Halaas JL, Gajiwala KS, Maffei M, Cohen SL, Chait BT, Rabinowitz D, et al. Weight-reducing effects of the plasma protein encoded by the obese gene. Science. 1995;269(5223):543-6

151. Miyamoto S, Yasui Y, Tanaka T, Ohigashi H, Murakami A. Suppressive effects of nobiletin on hyperleptinemia and colitis-related colon carcinogenesis in male ICR mice. Carcinogenesis. 2008;29(5):1057-63.

152. Ogunwobi OO, Beales IL. Cyclo-oxygenase-independent inhibition of apoptosis and stimulation of proliferation by leptin in human colon cancer cells. Dig Dis Sci. 2007;52(8):1934-45.

153. Fenton Jl, Lavigne JA, Perkins SN, Liu H, Chandramouli GV, Shih JH, et al. Microarray analysis reveals that leptin induces autocrine/paracrine cascades to promote survival and proliferation of colon epithelial cells in an Apc genotype-dependent fashion. Mol Carcinog. 2008;47(1):9-21.

154. Bergstrom A, Pisani P, Tenet $V$, Wolk A, Adami HO. Overweight as an avoidable cause of cancer in Europe. Int J Cancer. 2001;91(3):421-30.

155. Chia VM, Newcomb PA, Lampe JW, White E, Mandelson MT, McTiernan $\mathrm{A}$, et al. Leptin concentrations, leptin receptor polymorphisms, and colorectal adenoma risk. Cancer Epidemiol Biomark Prev. 2007;16(12):2697-703.

156. Park J, Scherer PE. Adipocyte-derived endotrophin promotes malignant tumour progression. J Clin Invest. 2012;122(11):4243-56.

157. Park J, Scherer PE. Endotrophin in the tumour stroma: a new therapeutic target for breast cancer? Expert Rev Anticancer Ther. 2013;13(2):1113. doi:10.1586/era.12.164.

158. Gregor MF, Hotamisligil GS. Inflammatory mechanisms in obesity. Annu Rev Immunol. 2011;29:415-45.

159. Yehuda-Shnaidman E, Schwartz B. Mechanisms linking obesity, inflammation and altered metabolism to colon carcinogenesis. Obes Rev. 2012;13(12):1083-95.

160. Hursting SD, Dunlap SM. Obesity, metabolic dysregulation, and cancer: a growing concern and an inflammatory (and microenvironmental) issue. Ann N Y Acad Sci. 2012;2012:82-7.

161. Vazzana N, Riondino S, Toto V, Guadagni F, Roselli M, Davi G, et al. Obesity-driven inflammation and colorectal cancer. Curr Med Chem. 2012;19(34):5837-53.

162. Gilbert CA, Slingerland JM. Cytokines, obesity, and cancer: new insights on mechanisms linking obesity to cancer risk and progression. Annu Rev Med. 2013;64:45-57.

163. Hwang WL, Yang MH, Tsai ML, Lan HY, Su SH, Chang SC, et al. SNAIL regulates interleukin-8 expression, stem cell-like activity, and tumourigenicity of human colorectal carcinoma cells. Gastroenterology. 2011;141(1):279-91.

164. Shah MS, Fogelman DR, Raghav KP, Heymach JV, Tran HT, Jiang ZQ, et al. Joint prognostic effect of obesity and chronic systemic inflammation in patients with metastatic colorectal cancer. Cancer. 2015;14:2968-75.

165. Taniguchi K, Karin M. IL-6 and related cytokines as the critical lynchpins between inflammation and cancer. Semin Immunol. 2014;26(1):54-74.

166. Lee EY, Lee ZH, Song YW. CXCL10 and autoimmune diseases. Autoimmun Rev. 2009;8(5):379-83.

167. O'Toole A, Michielsen AJ, Nolan B, Tosetto M, Sheahan K, Mulcahy HE, et al. Tumour microenvironment of both early- and late-stage colorectal cancer is equally immunosuppressive. Br J Cancer. 2014;111(5):927-32.

168. Park-Min KH, Antoniv TT, Ivashkiv LB. Regulation of macrophage phenotype by long-term exposure to IL-10. Immunobiology. 2005:210(2-4):77-86.
169. Lumeng CN, Bodzin JL, Saltiel AR. Obesity induces a phenotypic switch in adipose tissue macrophage polarization. J Clin Invest. 2007;117(1):175-84.

170. Edin S, Wikberg ML, Dahlin AM, Rutegard J, Oberg A, Oldenborg PA, et al. The distribution of macrophages with a M1 or M2 phenotype in relation to prognosis and the molecular characteristics of colorectal cancer. PLoS One. 2012;7(10):15

171. Wong SC, Puaux AL, Chittezhath M, Shalova I, Kajiji TS, Wang X, et al. Macrophage polarization to a unique phenotype driven by B cells. Eur J Immunol. 2010;40(8):2296-307.

172. Mantovani A, Allavena P, Sica A, Balkwill F. Cancer-related inflammation. Nature. 2008;454(7203):436-44.

173. Mantovani A. B cells and macrophages in cancer: yin and yang. Nat Med. 2011;17(3):285-6. doi:10.1038/nm0311-285.

174. Galon J, Mlecnik B, Bindea G, Angell HK, Berger A, Lagorce C, et al. Towards the introduction of the 'Immunoscore' in the classification of malignant tumours. J Pathol. 2014;232(2):199-209.

175. Xiao Y, Freeman GJ. The microsatellite instable subset of colorectal cancer is a particularly good candidate for checkpoint blockade immunotherapy. Cancer Discov. 2015;5(1):16-8.

176. Prendergast GC, Smith C, Thomas S, Mandik-Nayak L, Laury-Kleintop $L$, Metz R, et al. Indoleamine 2,3-dioxygenase pathways of pathogenic inflammation and immune escape in cancer. Cancer Immunol Immunother. 2014;63(7):721-35.

177. Ogden CL, Carroll MD, Curtin LR, McDowell MA, Tabak CJ, Flegal KM. Prevalence of overweight and obesity in the United States, 1999-2004. JAMA. 2006;295(13):1549-55.

178. Physical status: the use and interpretation of anthropometry. Report of aWHO Expert Committee. World Health Organ Tech Rep Ser. 1995;854:1-452.

179. Guiu B, Petit JM, Bonnetain F, Ladoire S, Guiu S, Cercueil JP, et al. Visceral fat area is an independent predictive biomarker of outcome after firstline bevacizumab-based treatment in metastatic colorectal cancer. Gut. 2010;59(3):341-7.

180. Romero-Corral A, Somers VK, Sierra-Johnson J, Thomas RJ, CollazoClavell ML, Korinek J, et al. Accuracy of body mass index in diagnosing obesity in the adult general population. Int J Obes. 2008;32(6):959-66.

181. Patel GS, Ullah S, Beeke C, Hakendorf P, Padbury R, Price TJ, et al. Association of BMI with overall survival in patients with $\mathrm{MCRC}$ who received chemotherapy versus EGFR and VEGF-targeted therapies. Cancer Med. 2015:4(10):1461-71.

182. Wu S, Liu J, Wang X, Li M, Gan Y, Tang Y. Association of obesity and overweight with overall survival in colorectal cancer patients: a metaanalysis of 29 studies. Cancer Causes Control. 2014;25(11):1489-502.

183. Fedirko V, Romieu I, Aleksandrova K, Pischon T, Trichopoulos D, Peeters $\mathrm{PH}$, et al. Pre-diagnostic anthropometry and survival after colorectal cancer diagnosis in Western European populations. Int J Cancer. 2014;135(8):1949-60.

184. Slattery ML, Berry TD, Potter J, Caan B. Diet diversity, diet composition, and risk of colon cancer (United States). Cancer Causes Control. 1997;8(6):872-82.

185. Schulz MD, Atay C, Heringer J, Romrig FK, Schwitalla S, Aydin B, et al. High-fat-diet-mediated dysbiosis promotes intestinal carcinogenesis independently of obesity. Nature. 2014;514(7523):508-12.

186. Orlich MJ, Singh PN, Sabate J, Fan J, Sveen L, Bennett H, et al. Vegetarian dietary patterns and the risk of colorectal cancers. JAMA Intern Med. 2015;175(5):767-76.

187. Franco M, Bilal U, Ordunez P, Benet M, Morejon A, Caballero B et al. Population-wide weight loss and regain in relation to diabetes burden and cardiovascular mortality in Cuba 1980-2010: repeated cross sectional surveys and ecological comparison of secular trends. BMJ. 2013;2013(9).

188. Volkova E, Willis JA, Wells JE, Robinson BA, Dachs GU, Currie MJ. Association of angiopoietin-2, C-reactive protein and markers of obesity and insulin resistance with survival outcome in colorectal cancer. Br J Cancer. 2011;104(1):51-9.

189. Kostic AD, Gevers D, Pedamallu CS, Michaud M, Duke F, Earl AM, et al. Genomic analysis identifies association of Fusobacterium with colorectal carcinoma. Genome Res. 2012;22(2):292-8.

190. Flanagan L, Schmid J, Ebert M, Soucek P, Kunicka T, Liska V, et al. Fusobacterium nucleatum associates with stages of colorectal neoplasia development, colorectal cancer and disease outcome. Eur J Clin Microbiol Infect Dis. 2014;33(8):1381-90. 
191. Tahara T, Yamamoto E, Suzuki H, Maruyama R, Chung W, Garriga J, et al. Fusobacterium in colonic flora and molecular features of colorectal carcinoma. Cancer Res. 2014;74(5):1311-8.

192. Mima K, Nishihara R, Qian ZR, Cao Y, Sukawa Y, Nowak JA, et al. Fusobacterium nucleatum in colorectal carcinoma tissue and patient prognosis. Gut. 2015;2015(26):2015-310101.

193. Mima K, Sukawa Y, Nishihara R, Qian ZR, Yamauchi M, Inamura K, et al. Fusobacterium nucleatum and T Cells in Colorectal Carcinoma. JAMA Oncol. 2015;1(5):653-61.

194. Lippitz BE. Cytokine patterns in patients with cancer: a systematic review. Lancet Oncol. 2013;14(6):e218-28.

195. Krzystek-Korpacka M, Diakowska D, Kapturkiewicz B, Bebenek M, Gamian A. Profiles of circulating inflammatory cytokines in colorectal cancer (CRC), high cancer risk conditions, and health are distinct. Possible implications for CRC screening and surveillance. Cancer Lett. 2013;337(1):107-14

196. Di Caro G, Marchesi F, Galdiero MR, Grizzi F. Immune mediators as potential diagnostic tools for colorectal cancer: from experimental rationale to early clinical evidence. Expert Rev Mol Diagn. 2014;14(3):387-99.
197. Shah MS, Fogelman DR, Raghav KP, Heymach JV, Tran HT, Jiang ZQ, et al. Joint prognostic effect of obesity and chronic systemic inflammation in patients with metastatic colorectal cancer. Cancer. 2015;2015(14):29440.

198. Ho GY, Wang T, Gunter MJ, Strickler HD, Cushman M, Kaplan RC, et al. Adipokines linking obesity with colorectal cancer risk in postmenopausal women. Cancer Res. 2012;72(12):3029-37.

199. Ogino S, Chan AT, Fuchs CS, Giovannucci E. Molecular pathological epidemiology of colorectal neoplasia: an emerging transdisciplinary and interdisciplinary field. Gut. 2011;60(3):397-411.

200. Ogino S, Lochhead P, Chan AT, Nishihara R, Cho E, Wolpin BM, et al. Molecular pathological epidemiology of epigenetics: emerging integrative science to analyze environment, host, and disease. Mod Pathol. 2013;26(4):465-84

201. Renehan AG, Tyson M, Egger M, Heller RF, Zwahlen M. Body-mass index and incidence of cancer: a systematic review and meta-analysis of prospective observational studies. Lancet. 2008;371(9612):569-78.

\section{Submit your next manuscript to BioMed Central and we will help you at every step:}

- We accept pre-submission inquiries

- Our selector tool helps you to find the most relevant journal

- We provide round the clock customer support

- Convenient online submission

- Thorough peer review

- Inclusion in PubMed and all major indexing services

- Maximum visibility for your research

Submit your manuscript at www.biomedcentral.com/submit
() Biomed Central 